\begin{tabular}{|l|l|l||}
\hline \multicolumn{2}{|c|}{ PublisherInfo } \\
\hline \hline PublisherName & $:$ & BioMed Central \\
\hline \hline PublisherLocation & $:$ & London \\
\hline \hline PublisherImprintName & $:$ & BioMed Central \\
\hline \hline
\end{tabular}

\title{
A cell of few modes
}

\begin{tabular}{||l|l|l||}
\hline \multicolumn{2}{|c|}{ ArticleInfo } \\
\hline \hline ArticleID & $:$ & 3730 \\
\hline \hline ArticleDOI & $:$ & $10.1186 /$ gb-spotlight-20000721-01 \\
\hline \hline ArticleCitationID & $:$ & spotlight-20000721-01 \\
\hline \hline ArticleSequenceNumber & $:$ & 167 \\
\hline \hline ArticleCategory & $:$ & Research news \\
\hline ArticleFirstPage & $:$ & 1 \\
\hline \hline ArticleLastPage & $:$ & 2 \\
\hline \hline & & \\
\hline ArticleHistory & $:$ & RegistrationDate : 2000-07-21 \\
\hline \hline ArticleCopyright & $:$ & OnlineDate $: 2000-07-21$ \\
\hline \hline ArticleGrants & $:$ & \\
\hline \hline ArticleContext & $:$ & 130591111 Central Ltd2000 \\
\hline \hline
\end{tabular}




\section{William Wells}

Email: wells@biotext.com

In the July 18 Proceedings of the National Academy of Sciences Holter et al. subject existing microarray gene expression data to a kind of spectral analysis (Proc. Natl. Acad. Sci. USA 2000, 97:8409-8414). This process of singular value decomposition (SVD) yields a set of "characteristic modes" that, when summed, reconstitute the entire expression pattern. But Holter et al. find that just two or three of the modes are sufficient to describe the vast majority of the expression data. This shows that expression patterns are simple, usually undergoing a single "on to off" or "off to on" transition in response to a perturbation. Analysis of cell cycle data suggests that generally genes are not activated or repressed in large, discrete groups, as previously thought, but that cell cycle progression is a smooth function with roughly equal numbers of expression changes per unit time.

\section{References}

1. Proceedings of the National Academy of Sciences, [http://www.pnas.org/]

2. Comprehensive identification of cell cycle-regulated genes of the yeast Saccharomyces cerevisiae by microarray hybridization.

This PDF file was created after publication. 